2020 Global Marketing Conference at Seoul Proceedings: 480-484 (November 2020) https://doi.org/10.15444/GMC2020.04.06.02

\title{
EXPLORING YOUNG ARTISTS' DIGITAL PERFORMANCE: THE IMPACT OF ONLINE COMMUNITY ENGAGEMENT AND CO-CREATION ON BRAND LOVE
}

\author{
Pedro Policarpo, Instituto Universitário de Lisboa (ISCTE-IUL), Portugal \\ João Guerreiro, Instituto Universitário de Lisboa (ISCTE-IUL), Portugal ${ }^{1}$ \\ Sandra Maria Correia Loureiro, Instituto Universitário de Lisboa (ISCTE-IUL), Portugal ${ }^{2}$ \\ Ricardo Godinho Bilro, Instituto Universitário de Lisboa (ISCTE-IUL), Portugal ${ }^{3}$
}

\begin{abstract}
New music artists have been emerging in recent years through new digital platforms and streaming services. These platforms allow artists to build a community and interact with members who share the same tastes and ideas. Hence, new artists find success through their communities' support and engagement. The current paper explores the everexpanding connection between digital media and music - allowing fans and/or consumers to naturally build a sense of belonging to a community of a single artist and/or band (Brodie et al., 2013). Brand communities are also a place where artists and fans can develop a long-term relationship (Baldus et al., 2015) and in turn create valuable personalised experiences together (Prahalad \& Ramaswamy, 2004) that will result in higher levels of engagement, or brand love (Carroll \& Ahuvia, 2006; Vernuccio et al., 2015). Furthermore, the identity of an artist plays a direct role in the artist and fan relationship (He et al., 2012), as well as the artist's authenticity, which is dependent on perception (Moulard et al., 2015) and how involved a fan is, since one pays attention and behaves differently when one is involved (Zaichkowsky, 1986). Thus, the aim of this paper is to study the drivers of engagement and brand love in these communities and how they can be perceived and used favourably by the artists and/or bands. Even though there has been academic research about human brands and their influence towards consumers, - more recently Centeno \& Wang (2017) - this topic represents a gap in literature, as it will focus on human brands and their communities, how their engagement levels react accordingly, and what characteristics are important for a human brand to be engaging to their public.
\end{abstract}

A human brand can be characterised as "any well-known persona who is the subject of marketing communication efforts" (Thomson, 2006, p. 104), for instance, any celebrity can fit the role of a human brand as his/her online and offline interactions can be described as marketing techniques - an artist may represent a celebrity or an icon to the fans, however, he is still susceptible to marketing associations. Therefore, artists or bands are human brands as they "can be professionally managed" and "have additional associations and features of a brand" (Thomson, 2006, p. 105). The human brand identity

\footnotetext{
1 joao.guerreiro@iscte-iul.pt

2 sandramloureiro@netcabo.pt

${ }^{3}$ bilro.ricardo@gmail.com
} 
can be formed through the process of co-creation, as "both individuals and community members are relevant to marketing efforts" (p. 133). Furthermore, co-creation, as stated previously by Prahalad and Ramaswamy (2004), is about joint creation of value and experiences between the consumer and the brand; it serves the goal of aligning brand identity and brand perception (Kennedy \& Guzmán, 2016). Henceforth, human brand identities undergo a process of co-creation among three groups of stakeholder-actors: (1) focal stakeholder-actor, (2) primary stakeholder-actor, and (3) instrumental stakeholderactor. While the first two engage with the human brand since they feel the need to do so - "They feel social legitimacy to react, 'comment', express opinions to, and even eroticize celebrities" (Centeno \& Wang, 2017, p. 135) the instrumental stakeholder-actor represents the media outfits, advertisers, talent agencies, amongst others. Therefore, we posit that: Brand Identity has a positive effect on Brand Community Engagement (H1a); Brand Identity has a positive effect on Co-creation (H2a). Similar to the previous concept of Brand Identity, Authenticity is quite significant to the identity of a music artist as well - "Authenticity has been shown to be critical in building brand identity to differentiate the brand" (Keller, 1993; Preece, 2015, p. 619), which makes Authenticity instrumental for building value and character to the brand. Marshall \& Forest (2011), and later Moulard, Rice, Garrity, \& Mangus (2014), concluded that an artist's authenticity will positively affect the consumers' attitude towards that artist; that is to say, if a human brand is passionate and shows care for his/her craft, that same human brand will be perceived as more authentic (Moulard et al., 2014). Bands who find success early on and begin to incorporate more commercial aspects into their sound are often seen as "sell outs" or inauthentic by their fans. Hence, the sound and music an artist makes can reflect authenticity to the fans. Consequently, the perceived authenticity of a human brand by a consumer may lead to increased attachment to that same human brand (Thomson, 2006). Hence: Authenticity has a positive effect on Brand Community Engagement (H3a). Co-creation, which has as its main pillar a joint creation of value, makes authentic brands more desirable for consumers to engage in the process of cocreation. "Consumers often purchase brands for the many positive benefits they represent" (Lee, Motion, \& Conroy, 2009, p. 169); they want to express their identities, and which brands they want to be linked with and which ones they do not (Lee et al., 2009). Therefore, Authenticity is "central to the meaning-making process as it is through a negotiation of authenticity that the public engages with celebrity." (Preece, 2015, p. 619). Consequently, consumers should be more interested in participating, in 'being included in the same story' of the brand: Authenticity has a positive effect on Co-creation (H4a). Considering a human brand perspective, involvement may also be reflected on the characteristics of that human brand, or the surrounding environment and its community, that lead interested individuals to get involved and to interact. Involvement arises from the need to connect and know more about the brand (Zaichkowsky, 1985); to participate and to interact in online communities about the human brand - to socialise; understand more about the human brand through different media. It is an antecedent of Consumer Brand Engagement, as it was identified by Hollebeek et al. (2014). Likewise, the need to get involved with a music artist may lead to socialisation in a community dedicated to that music artist. Therefore: Involvement has a positive effect on Brand Community Engagement (H5a) and co-creation (H6a). Finally Brand Love is quite often the result of a long-term relationship between the consumer and the brand (Carroll \& Ahuvia, 
2006). It is formed through a continuous dialogue between both parties, as well as an incorporation of co-creational aspects in the relationship, for instance, a joint creation of personalised experiences (Prahalad \& Ramaswamy, 2004). On a specific note, brand love frameworks reflect several concepts, such as brand acceptance and brand loyalty, positive word-of-mouth, or even a resistance to negative information about the brand (Carroll \& Ahuvia, 2006; Vernuccio et al., 2015). Building upon Carroll \& Ahuvia (2006) definition of brand love, human brand love or, more specifically, music artist's brand love can be defined as the intense and emotional attachment an engaged fan has towards a specific music artist. Human brand love or music artist's brand love will be the last step on the further conceptual model, being the consequence of the human brand engagement. Hence, Brand Community Engagement has a positive effect on Brand Love (H1b) and Cocreation has a positive effect on Brand Love (H2b). Before the current study was conducted, a small pre-test was performed by twenty previously chosen respondents to choose the final artists to include in the experiment. "Post Malone", "twenty one pilots", and "Capitão Fausto" were selected due to their acceptance in terms of Brand Identity and Past Experience. A survey was conducted from April 22 to June 30. The data was collected online, mostly gathered in two websites, Facebook and LinkedIn. In both cases, the study was posted on the main page of the author, sent to people through chat, and,

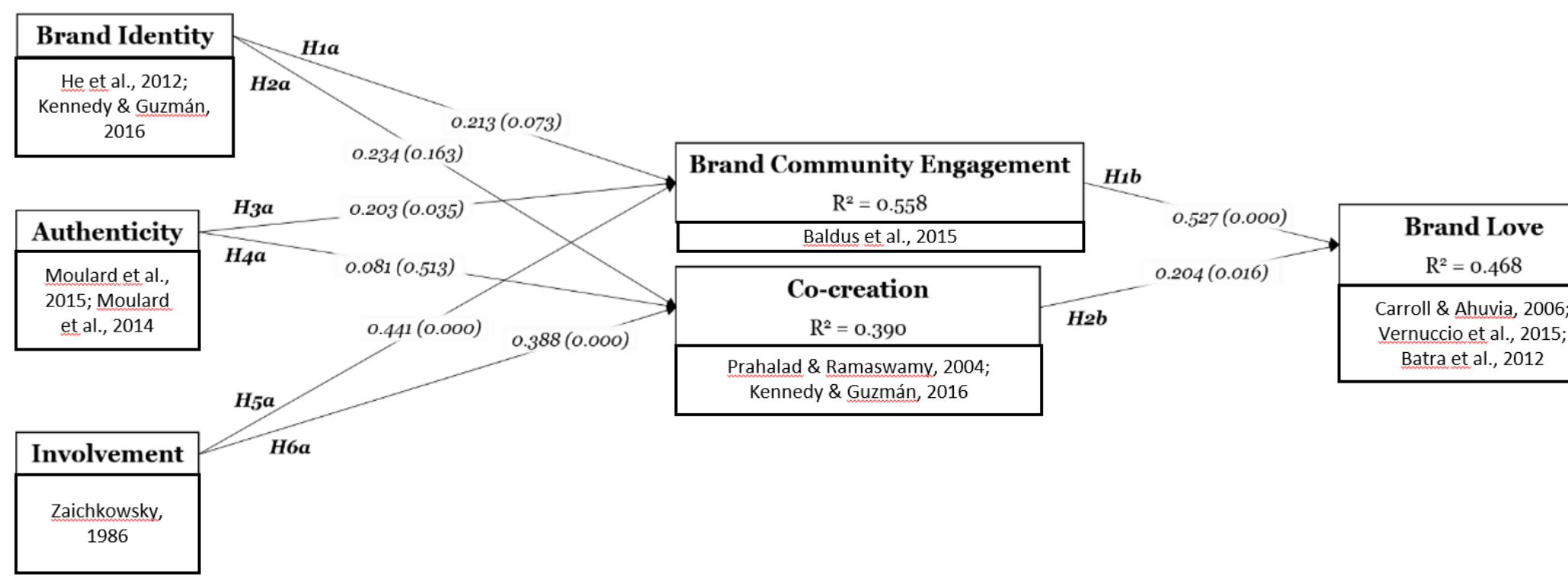

regarding Facebook, it was posted on specific groups where the members respond and post new questionnaires daily. A total of 133 responses were collected, 130 of those being eligible and 3 having missing values. The sample's mean age was approximately 24 years old, being most respondents aged between 22 and 24. PLS-SEM was chosen to test the proposed hypotheses. Concerning the reliability of the model all constructs revealed acceptable Cronbach Alpha, CR and AVE measures with a SRMR of .07 for the saturated model and .10 for the estimated model. Figure 1 shows the conceptual model along with the results and original scales used in the study.

Figure 1 - Conceptual Model and PLS-SEM results 
Results show that Involvement has a strong relationship with Brand Community Engagement ( $\mathrm{H} 5 \mathrm{a}$ is supported) and co-creation (H6a is supported). The link between Authenticity and Co-creation, however, seems to be weak and not significant (H4a was not supported), as well as the links between Brand Identity and Brand Community Engagement (H1a) and Brand Identity and Co-creation (H3a). Authenticity, however, does have a significant connection to Brand Community Engagement (H3a is supported). Finally, both brand community engagement and co-creation seems to have a positive effect on Brand Love ( $\mathrm{H} 1 \mathrm{~b}$ and $\mathrm{H} 2 \mathrm{~b}$ is supported). This study shows that if fans are apt to co-create based on how involved they are with the band, managers may promote specific music events to involve them. Also, reinforcing the authenticity of the band may increase engagement in the brand community. Such engagement and co-creation desires reinforce the sense of love towards the band and may therefore create long-standing and unique relationships.

Keywords: human brands; brand community engagement; co-creation; brand love.

\section{References}

Baldus, B. J., Voorhees, C., \& Calantone, R. (2015). Online Brand Community Engagement: Scale Development and Validation. Journal of Business Research, 68, 978-985.

Brodie, R. J. Ilic, A., Juric, B. \& Hollebeck, L. (2013). Consumer Engagement in a Virtual Brand Community: An Exploratory Analysis. Journal of Business Research, 66, 105-114.

Carroll, B. A. \& Ahuvia, A. C. (2006). Some Antecedents and Outcomes of Brand Love. Springer Science + Business Media, 17, 79-89.

Centeno, D. \& Wang, J. J. (2017). Celebrities as Human Brands: An Inquiry on Stakeholder-actor Co-creation of Brand Identities. Journal of Business Research, 74, 133-138.

Chernatony, L. \& Riley, F., D. (1998). Defining a "Brand": Beyond the Literature with Experts' Interpretations. Journal of Marketing Management, 14, 417-443.

He, H., Li, Y., \& Harris, L. (2012). Social Identity Perspective on Brand Loyalty. Journal of Business Research, 65, 648-657.

Hollebeck, L. D., Glynn, M. S. \& Brodie, R. J. (2014). Consumer Brand Engagement in Social Media: Conceptualization, Scale Development and Validation. Journal of Interactive Marketing, 28, 149-165.

Keller, K. L. (1993). Conceptualizing, measuring, and managing customer-based brand equity. Journal of Marketing, 57(1), 1-22.

Kennedy, E., \& Guzmán, F. (2016). Co-creation of Brand Identities: Consumer and Industry Influence and Motivations. Journal of Consumer Marketing, 33(5), 313-323

Marshall, K. P., \& Forrest, P. J. (2011). A framework for identifying factors that influence fine art valuations from artists to consumers. Marketing Management Journal, 21, 111-123.

Moulard, J. G., Rice, D. H., Garrity, C. P., \& Mangus, S. M., D. H. (2014). Artist Authenticity: How Artists' Passion and Commitment Shape Consumers' Perceptions and Behavioral Intentions Across Genders. Psychology \& Marketing, 31(8), 576-590. 
Moulard, J. G., Garrity, C. P., \& Rice, D. H. (2015). What Makes a Human Brand Authentic? Identifying the Antecedents of Celebrity Authenticity. Psychology \& Marketing, 32(2), 173-186.

Prahalad, C. \& Ramaswamy, V. (2004). Co-creation Experiences: The Next Practice in Value Creation. Journal of Interactive Marketing, 18(3), 5-14.

Preece, C. (2015). The authentic celebrity brand: unpacking Ai Weiwei's celebritised selves. Journal of Marketing Management, 31(5-6), 616-645.

Thomson, M. (2006). Human brands: Investigating Antecedents to Consumers' Strong Attachments to Celebrities. Journal of Marketing, 70, 104-119.

Vernuccio, M., Pagani, M., Barbarossa, C., \& Pastore, A. (2015). Antecedents of Brand Love in Online Network-based Communities. A Social Identity Perspective. Journal of Product \& Brand Management, 24(7), 706-719.

Zaichkowsky, J. L. (1985). Measuring the Involvement Construct. Journal of Consumer Research, 12, 341-352.

Zaichkowsky, J. L. (1986). Conceptualizing Involvement. Journal of Advertising, 15(2), 4-34. 